\title{
Syrjäytyvät unohdetaan "erinomaisuuden ethoksen" takapihalle
}

Jauhiainen A., Rinne R. \& Tähtinen J. (toim.) 2001: Koulutuspolitiikka Suomessa ja ylikansalliset mallit. Suomen Kasvatustieteellinen Seura.

\section{Kasvatustieteilijöiden ja} opetusalan ammattilaisten tieteellinen seura on perustanut uuden julkaisusarjan, Kasvatusalan tutkimuksia, jonka näyttävä (406 sivua) avaus teos on. Se sisältää toimittajien esittelyartikkelin lisäksi 18 Kasvatustieteen päivillä pidettyä esitelmää tai niistä muokattua artikkelia. Pakostakin teoksesta on muodostunut moniaineksinen, mikä tekee vaikeaksi kirjan käyttämisen kurssikirjana. Kaikki artikkelit eivät liity kirjan otsikkoon ja vielä harvempi esittelee mitään malleja, mutta koulutuspolitiikkaa jokainen nakertaa jostakin kulmasta. Itse asiassa kuitenkin vain yksi koulutusmalli esitellään ja analysoidaan perusteellisesti: koulutustarjonnan markkinavoimille alttiiksi jättämä uusliberalistinen ohjausmalli, jonka artikkelit katsovat johtavan luopumiseen keskeisestä pohjoismaisesta periaatteesta, tasa-arvon edistämisestä koulutusinstituution avulla. Koulutuspoliittisten valintojen katsotaan johtavan nuorten syrjäytymiseen, syventävän sukupuolten välisiä eroja ja raunioittavan yhteisen peruskoulun.

\section{Johdantoartikkeliksi on} osuvasti valittu Lontoon yliopistossa vaikuttavan terävän kriitikon Stephen Ballin artikkeli yhdentävästä globaalista koulutuspolitiikasta ja kansallisen politiikan mahdollisuuksista tässä pakkopaidassa. Nostaisin esiin erityisesti hänen kommenttinsa suorituskeskeisyydestä, josta Hannu Simola on käyttänyt nimitystä erin-

omaisuuden ethos. Se on kaventanut koulutustavoitteet kokonaisen ihmisen kasvattamisen päämäärästä veistetyiksi, standardikokeilla mitattaviksi ohuiksi siivuiksi ja houkutellut koulujen välisten tuloksellisuuslistojen julkaisemiseen tulosvastuun ja vanhempien tiedon saannin nimissä. Ball on viehtynyt erilaisten kielikuvien ja tiiviiden nimilappujen viljelyyn, mikä panee kääntäjät koville.

\section{Toinen "vieraileva tähti"} on Sverker Lindblad Uppsalan yliopistosta. Hänen artikkeliaan voin kuvailla pedagogiseksi. Lindblad suhtautuu varauksellisesti yhä uusiin poikkileikkausluonteisiin empiirisiin tutkimuksiin. Jos koulutusideologian ja koulutusrakenteiden muutoksia ja niiden yhteyksiä hyvinvointivaltion muutoksiin haluaa ymmärtää, on omaksuttava metatutkimuksellinen ja syntetisoiva lähestymistapa. Kirjoittaja esittää metodologisen kehyksen, jossa hän tarkastelee 35 vuoden ajalta keskeisiä yksittäisiä tapauksia ja trendejä, jotka viitoittavat tietä koulutusrakenteiden ja -sisältöjen muutokseen. Hänen tapansa tehdä lyhyessäkin artikkelissa välitilinpäätöksiä, ja ”mitä opimme" tiivistelmiä tekevät helpoksi kirjoittajan ajatteluprosessin seuraamisen ja oman kokemuksen vertaamisen kirjoittajan johtopäätöksiin. Artikkeli käy metodisesta opastuksesta painavan sisältönsä lisäksi. Siksi kutsun lähestymistapaa pedagogiseksi.

\section{Mielenkiintoinen}

yksityiskohta on sosiologien usein esittämä väite koulutusinflaation mukanaan tuomasta koulutuksen taloudellisen ostovoiman heikentymisestä.

Taloustieteelliset tutkimukset, muun muassa tuore kaikki EU-maat kattava PURE-ohjelma osoittaa toista, tai ainakin sen, että taloudellinen hyöty koulutuksesta vaihtelee maittain paljon ja joissakin maissa koulutuksen ja taloudellisen hyvinvoinnin yhteys on vahvistunut. Useimmat tuntuvat kuitenkin Lindbladin tapaan olevan yhtä mieltä siitä, että universaalinen korkeakoulutus tehostaa koulutuksen valikointitehtävää. Ne, jotka jättävät koulutuksensa oppivelvollisuuskouluun tai keskeyttävät sen, ovat vaikeasti integroitavissa yhteiskuntaan minkään turvaverkkojen avulla. Heistä syntyy yhteiskunnan uusi alaluokka.

\section{Kirjassa on monia}

vakuuttavia ja perinpohjaisia artikkeleita koulutusajattelun muutoksesta. Sirkka Ahonen (Kuka tarvitsee yhteistä koulua) antaa erinomaisen prosessikuvauksen uusliberalistisen koulutusajattelun etenemisestä intressiryhmä- ja po- 
liittisen keskustelun tasolla. Jyrki Hilpelän viileä, kielikuvilla mässäilystä pidättyvä analyysi uusliberalistisen koulutuspolitiikan aatteellisesta taustasta olisi sopinut hyvin teoksen johdantoartikkeliksi. Risto Rinteen laaja esitys koulutuspolitiikan käänteestä ja nuorten syrjäytymisestä on terveellinen muistutus siitä, että koulutuspolitiikalla voidaan saada (tai olla saamatta) muutakin aikaan kuin kohonneita koulusaavutustestien pistemääriä kansainvälisiin tilastoihin.

\section{Useimmat artikkelit}

perustuvat empiiriseen tutkimukseen, jolloin lukijalla on mahdollisuus validoida johtopäätöksiä omistakin lähtökohdistaan. Toimittajat esittelevät johdannossa jokaisen artikkelin ja piirtävät yleisen kehyk- sen, jossa artikkeleita pitää tarkastella. Loppuun jäi kaipaamaan jonkinlaista synteesiä tai tulkintaa kirjavasta kokoelmasta, mutta urakka olisi ollut varmasti vaikea. Tuhti ja eri asioista kiinnostuneille ja eri asioita tutkivalle hyödyllinen pienoiskirjasto, joka vaatii runsaasti aikaa lukea ja sulatella.

Reijo Raivola 